\title{
INDONESIA - FREEPORT ECONOMIC DISPUTE
}

\author{
Farah Redina Azaria \\ Universitas Indonesia \\ Email: farahredina@gmail.com
}

\begin{abstract}
ABSTRACK
PT. Freeport Indonesia began operating in the Mimika district in Papua Province at the Gresberg mining. Their cooperation with Indonesia was marked with a contract of work I (Kontrak Karya / KK), with contract period of 30 years. The contract was made after the legalization of the investment LAW on 7 April 1967. This cooperation had been going long when KK II was established. However, in 2017 there was a change of regulation of natural resources management of Indonesia namely IUPK (Izin Usaha Pertambangan Khusus). This regulation initiated debate between Freeport and Indonesia government to reach a consensus. The method used to collect data in this study is qualitative method. Using mercantilist theory, this study suggests that state income and gains are major aspect in international cooperation .
\end{abstract}

Keywords : Indonesia, Freeport, Mercantilism, and Foreign Policy

\section{INTRODUCTION}

PT. Freeport Indonesia has carried out its exploration since the era of President Soeharto, in the early days of the New Order government there was a law on investment in Indonesia, namely Law number 1 of 1967 concerning foreign investment (UU PMA). The existence of this Law is expected to bring benefit to Indonesia and provide prosperity for its people. Freeport began its interest in conducting PMA since a geological expert, Forbes Wilson, was sent by Indonesia to conduct exploration in 1959. After the exploration, Willson discovered Ertsberg with its mining resources (Leith Denise, 2002)

At first, the unstable condition of Indonesia made Freeport worried to cooperate with Indonesia. Considering Indonesia was also still prone to conflict which it would possibly result in losses for Freeport. In addition, it was also found that there was a difficulty in access of transporting mining equipment and It required a months to do the exploration in the region (Ibid, pg.2) However, Freeport succesfull found the mining resource at the esploration and at the end they finally decided to invest in Indonesia, marked by Kontrak Karya (KK) I.

Ertsberg has a very large reserve of resources and therefore the Indonesian government made Kontrak Karya which is an agreement between the Government of Indonesia and PT. Freeport where each party has their respective obligations and requirements. The Government of Indonesia as the sole right in the ownership of the area gives its rights to PT. Freeport Indonesia 
(PTFI) to explore, deviate, operate, market and sell minerals or products from the mine in the area (PT. Freeport Indonesia, 2014)

After the exploration and discovery of Grasberg with a large natural resource reserve, Freeport required a large investment in Indonesia so there was the need to extend Kontrak Karya for legal certainty in carrying out operations in Grasberg. It made Kontrak Karya II happen in 1991 (PT. Freeport Indonesia, 2014).

The main production produced by Freeport is copper, copper also has high profit results if it has been processed to be used as daily necessities such as materials for making cars, planes, communication devices, electric cables, pipes and so on. Of course the existence of Freeport and copper-based production and other natural resources are expected to help in the welfare of the Indonesian people, especially if the natural resources processed come from Indonesia.

The cooperative relationship between Indonesia and Freeport has been running for more than 50 years, Freeport is also an effort that gave rise to the first foreign investment in Indonesia. With the emergence of new regulations regarding changes in regulations and the relocation of laws from Kontrak Karya to an IUPK, there is tension in cooperation between the two parties, there is an assumption and estimation that Freeport will incur losses for Indonesia and lack justice in conducting cooperation with Indonesia.

Mining management with this kind of Kontrak Karya brings drawback to Indonesia because the position between countries and foreign companies is aligned, the parallel position has an impact on the Indonesian government, it is difficult to conduct supervision and control production (Ali Imron, 2013)

Nonetheless, PTFI, in reality, in carrying out its activities is based on Kontrak Karya regulations in which all PTFI activities are under the supervision of the Indonesian government and related institutions (Chappy Hakim, 2019) With the new regulations regarding the cooperation between Indonesia and PTFI, it also makes PTFI in a difficult position in carrying out its activities. Indonesia is said to have been successful in playing a role in pressuring Freeport to approve the conversion of Kontrak Karya to an IUPK, because it was not easy to implement the change of the law that had been implemented since 1991.

It is also unavoidable that Freeport has a positive impact on developments for Indonesia, where Freeport has made countless contributions to the growth of the Indonesian people, not only in terms of its economy but also in terms of health, education, culture, employment and several other aspects which help in growth and prosperity for Indonesia. 
Taking a look at Henry Toruan D. Lbn's (2015) Literature Review on the Shifting Legal Paradigm in Mining Investment, it is explained that the policy of the New Order government towards the 1945 Constitution paragraph (3) that "The earth and water and the natural wealth contained therein are controlled by the state and is used for the greatest prosperity of the people ", but according to Henry's view that welfare has not arrived where four decades have passed while Indonesia's natural resources are increasingly depleting (Toruan, Henry D, 2015)

It can be seen from the view of Henry's (2015) view that Freeport does not always benefit Indonesia and with problems like this that encourage the Indonesian government to change the Kontrak Karya regulations that have been used from the new order era to IUPK, so that Indonesia can be prosperous nation that brings prosperity for the community and the economic development of the country, which is in accordance with the 1945 Constitution (3) concerning the welfare of the Indonesian people.

The description above arises few questions, what are the implications of cooperation between Freeport and Indonesia in the New Order of President Soeharto's era to current days and how is the role of the Government of Indonesia in providing encouragement to PTFI in turning a Kontrak Karya into a Special Mining Business License?

\section{FRAMEWORK ANALYSIS}

In analysing this journal, Mercantilism approach can be also used to explain the role of Indonesian government in pressuring PTFI parties to approve the changes of Kontrak Kerja law to IUPK. Mercantilism approach is one of theory that describes European trading system in the 16 th century to the end of the 18 th century.

Mercantilism considers that the interests and revenues of the state are the main aspects in conducting international cooperation. Of course, cooperation profits the country (Lahaye Laura, 2019) According to experts the meaning of Mercantilist is fortunate, beside that the experts also hold that mercantilist includes the belief that the state must actively interfere in the economic process to control and encourage the development of its country (Moritz Isenmann).

In addition to mercantilists looking at the active role of a country, they also provide concepts in export development. Especially in the field of promoting domestic industries such as horticultural manufacturing such as agriculture, plantations and so on. Of course if it is associated with cooperation between Indonesia and Freeport, of course there are interests from both sides. 
Connecting it to mercantilist theory with the meaning of profit, the interest of Freeport is only to gain more profit from Indonesia. In addition, the benefits obtained by Freeport can be seen from the implementation of the Indonesian KK Law which is considered to provide more benefits to Freeport in terms of profit or in carrying out exploration in Papua.

Where the policy is considered not comparable with the benefits obtained by Indonesia. Apparently, the law of $\mathrm{KK}$ applied by Indonesia is contrast to the mercantilist approach where the country should get more profit and must play an active role in the country's economic activities.

As it was debated, the change of the KK to the IUPK certainly coincided with the Mercantilist approach where Indonesia as a state actor and played its power to pressure Freeport to approve the policy, of course the policy would benefit Indonesia more. The purpose of Indonesian government took that action was mainly to provide benefits and prosperity to the Indonesian state itself.

\section{RESEARCH METHODS}

This research uses qualitative method with case study. It is a method that obtains data from literature and case study. Case study that is used in this research is the change of Indonesian law witch was used to named Kontrak karya to IUPK. This change basically gives impact on the cooperation among Indonesia and several companies, PT. Freeport is one of them.

\section{DISCUSSION}

\section{New order of PTFI}

The glorious moment of PTFI can be seen from the reign of President Soeharto's new oder in 1967, at first PTFI established relationships with Indonesian elites with that closeness, thus establishing cooperative relations between PTFI and Indonesia. At the beginning of the policy, President Soeharto requested that PTFI give $8.9 \%$ equity in its operations, with an agreement between the two parties PTFI began its activities in Papua and succeeded in finding gold and silver in Ertsberg (Denise leith, 2002)

After establishing cooperation and PTFI explored in 1991 and 1994 Freeport and signed two new contracts, where in the new contract in 1991 there was a change in equity given to Indonesia to be $10 \%$, besides President Soeharto asked Freeport to share dividends by $40 \%$ and the request was granted by Freeport (Denise leith, 2002). If it is seen at the beginning of Freeport existence, Freeport itself came from law of PMA, where it is a law created in the transition of leadership era of Soeharto aimed to interest foreign investors to make the national economy 
better. The creation of PMA law made Freeport become the first foreign company that signed the contract, as well as become the only foreign company that did its investment in Indonesia.

Thus Freeport found it easier in Soeharto era in implementing tax policy, in the KK Law Freeport get tax exemption for three years in Soeharto era (Denise leith, 2002). However, Indonesian government did not only give an open access for Freeport for creating economy stability but also there was a politic aspect involved. According to the Indonesian Institute of Sciences (LIP), the exclusive rights and facilities granted by President Suharto to Freeport were not without conditions, where the American company was used as a political tool for Suharto in the international system. Suharto used Freeport not only in economic and business aspects but also to sustain Indonesia and its politics in international systems like PBB (Denise leith, 2002). The PTFI Contract of Work was given ease in carrying out its activities such as PTFI dividend profits which were higher than Indonesia and the elimination of several taxes for PTFI.

\section{The Impact of PTFI in Indonesia}

The cooperation between Freeport and Indonesia brought both positive and negative impact. In the positive side, beside the higher number of job vacancies than before, Indonesia also got technological support from the original country of Freeport. But the negative was unfortunately outweighed its positive.

Firstly, it can be seen from the economic imbalance between PTFI and Indonesia, also Indonesia had low bargaining power in Kontrak Karya of PTFI, where it was actually stated in the contract that both have to be in the same position. In addition, there was another finding that the misused of position happened in the era of Pesident Soeharto, (Ahmad Redi, 2016) connected this issue to the content of the Constitution of the Republic Indonesia (UUD) 1945, that the result form using of Indonesia's natural resources should be given as much as possible to its people (Ahmad Redi, 2016).

Nevertheless, there are interests of "certain groups" in reality in natural resource management where in the new order of the Soeharto governance era, it controlled the political system in Indonesia. PTFI's mining-based business in the course of its work had impacted environmental problems on the surrounding area. During PTFI's exploration in Indonesia, PTFI developed a CSR program that contained environmental guarantees and communities in PTFI's work area. It was also stated that there was a program regarding reclamation or reforestation of unused land (D.F Pratiwi, 2019). Another fact that PTFI brought harm to the environment and health of people surrounding, this was based on the results of an audit conducted by Parametrix 
it was revealed that Tailling which was dumped by PT. Freeport is a material that produces acidic liquids and has a harmful impact on life and the surrounding environment (A.D Astuti, 2018).

In 2001 PTFI was sued by (WALHI) Wahana Lingkungan Hidup, associated with environmental pollution on Lake Wanagon which has dangerous and toxic elements. Even this problem was brought into legal channels, then the legal tribunal decided that PTFI was guilty and had to make an effort to repair it in the chaos it had done, government institutions and several government agencies were sent by the legal assembly to supervise PTFI's improvements and activities (A.D Astuti, 2018).

In addition to the problem of environmental pollution, PTFI faced some challenges with the inhabitants of Papua because it was considered to have carried out a large exploitation of the mines in Papua but did not provide prosperity for the surrounding community. (Amiruddin and Aderito Jesus de Soares, 2003) assess Freeport's activities believe that Freeport's activities were fully supported by the Government of Indonesia, which is a multinational corporation with the characteristic of only exploiting Indonesia's natural wealth without regard to the fate of the surrounding community (Amiruddin, Aderito, 2003).

The presence of Freeport was also considered as a penetration of an exploitative capitalism system where the main purpose of a company is only to make a profit and nothing but to exploit a country's natural resources and dominate the local environment both socio-culture or ecopolitic aspect (Amiruddin, Aderito, 2003).

This can be reviewed that the presence of PT. Freeport only brought several problems. In contrast to the idea that the emergence of foreign capital or foreign companies in a country will provide benefits and prosperity for a country.

\section{Change of Kontrak Karya to a Special Mining Business License}

Reviewing from a number of points listed in the presence of Freeport in Indonesia, it was considered, during the administration of President Jokowi, that Freeport's behaviour was not a natural thing and had been left for too long in its activities that were not controlled by the government system and Indonesian Law properly so that it provided less benefits for the welfare of the Indonesian people compared to the negative impacts obtained.

According to Government regulation Number 1 of 2017 (PP 1/2017) Mining companies holding Kontrak Karya (KK) must change their contracts in accordance with the new regulations that have been set, namely the Special Mining Business License (IUPK) in order to export the 
concentrate, the concentrate is a mineral that has been processed but has not yet reached the residential stage (Daniel Wahyu, 2019). The difference between KK and IUPK is regarding the tax application system, the IUPK tax liability is more prevailing by following the tax rules that have been applied such as taxes and tax royalties paid by Freeport at any time may change according to applicable regulations.

Whereas the KK is more nailed down, in which the taxes and royalties paid by Freeport have a large fixed cost and there is no change until the contract period expires (Daniel Wahyu, 2019). In addition, the difference between IUPK and KK itself can be seen from the role of domination between the two parties. The role of dominance that is fostered here is that Freeport in its activity period of more than 50 years can be said to be more dominating the benefits of cooperation and the freedom given in carrying out its exploration on Indonesian soil.

It has been known that the State should have got greater benefits from investments that come into a country, and the level of power of cooperation should be more dominated by the role of the state. The number of benefits obtained by Indonesia is less than Freeport did. Seeing the problem in the era of President Jokowi's administration imposed new regulations regarding cooperation between Freeport and Indonesia where the regulation was changed because Kontrak Karya of Freeport has ended, the new regulation states: (Peraturan Pemerintah Republik Indonesia Nomor 1 Tahun 2017)

Holders of IUP and IUPK in the context of foreign investment, after 5 (five) years of production are required to divest shares in stages, so that in the tenth year the shares are at least $51 \%$ (fifty one percent) owned by Indonesian participants. (Government Regulation of the Republic of Indonesia Number 1 of 2017, Article 97). With the enactment of the Indonesian Government's IUPK bargaining power regulations and policies it is certainly more dominant than Freeport so that it gives Indonesia the power to get the benefits that should have been obtained since the beginning of the collaboration between Freeport and Indonesia.

Besides PT. Freeport accepts to release $51 \%$ of its shares, PT. Freeport was also asked to build a smelter, purification and also accept the rules and context contained in the IUPK (Yoesry Erni, 2019). With the enactment of such regulations, it is expected to be able to provide more benefits compared to the previous works.

\section{The Role of Indonesia in IUPK approval}

Indonesia was involved in the approval of IUPK, Indonesia succeeded in putting pressure on Freeport in its business activities in Papua, the expiration of the Kontrak Karya which was 
changed to IUPK and pressure from the Government of Indonesia made Freeport obey the regulation, because if Freeport wanted to continue to carry out its product, operations activities should follow IUPK regulations. Based on article 170 of Law No. 4 of 2009 concerning Mineral and Coal, KK holders are required to purify within 5 years of the issuance of the Law, namely in 2014 (Andhika Akbaransyah, 2019)

Therefore Freeport as the KK holder could no longer carry out its activities in exporting its copper concentrate especially the main production field from Freeport is copper. This kind of pressure from the Government of Indonesia makes Freeport approve the conversion of KK to IUPK. Another reason for Freeport to approve this change is also because of the certainty in the contract renewal system so that Freeport can carry out its activities as before. With the emergence of requirements under Law No.4 of 2009 concerning Minerals and Coal, the extension of operations can be extended twice in ten years to 2041 (BBC News Indonesia, 2019).

Of course, in resolving problems between Freeport and Indonesia, both parties have benefited, Indonesia has given Freeport the policy that with the amendment of the IUPK, the company will continue to benefit. For example, in the taxation system that was changed to prevailing, where the Government of Indonesia said that the policy did not have a detrimental impact on Freeport, but if Freeport continued to use the principle of nailed down, the tax borne would tend to be greater in the future (BBC News Indonesia, 2019). From the role of Indonesia, Freeport has agreed to amend regulations because there is certainty in the extension of Freeport's operations, besides that there is also pressure from the Indonesian Government for Freeport to immediately approve IUPK regulations if it wants to carry out its export production. Where the Indonesian Government prohibits Freeport from continuing its activities before signing the KK change into IUPK.

However, Freeport also accepts IUPK to be a new mineral regulation because Freeport also continues to benefit the company, where the main objective to be achieved by Freeport in the regulation is the certainty of the extension of export production and Freeport's activities, which in the end Freeport has achieved it even in the IUPK, Freeport extend it until 2041 that will certainly benefit Freeport itself.

\section{CONCLUSION}

Indonesia's role in pressuring Freeport to approve IUPK was said to be successful, because Freeport had agreed and wanted to collaborate with Indonesia using the policy. Considering the 
history of cooperation between Freeport and Indonesia in the early days, especially the new order, Freeport had a high power where the status between the government and Freeport was equal, and there was also the closeness of Freeport with the elite elements during the new order of governance, thus providing a lot of willingness to carry out operational activities in Papua.

Other problems that always arise in Freeport's activities such as human rights, environmental damage, income and so on, are increasing. During Jokowi's administration, it was Indonesia's firm stance in overcoming the problem, namely making a new policy to rearrange cooperation with Freeport that could benefit Indonesia, one of which was the income or dividends obtained by Indonesia by $51 \%$ would certainly be a very increased profit compared to profits in previous era.

With pressure from the Government of Indonesia in encouraging Freeport to approve IUPK, it is expected to get valid benefits and the results of these benefits can bring prosperity both to the country and to the people of Indonesia, because the basic assumption of the existence of investors or PMA in Indonesia itself is to provide benefits that have more positive impact on development and welfare in Indonesia

The advice that can be given in the amendment to this collaboration must certainly be more positive and beneficial for Indonesia. In addition, PT. Freeport is expected to be able to solve the problems that occur, especially the impact of environmental damage and how to overcome it. In addition, the Government of Indonesia is expected to be firm in carrying out policies and laws in this IUPK, so that there is no longer an abuse of power by certain parties.

In addition, the Government of Indonesia is expected to be able to better maintain a more stable and clear legislation system as well as its political and economic system, because it is undeniable that in the development of Indonesia's economy, it is assisted by foreign capital coming in, such as capital, technology and knowledge that they carry certainly has a positive impact on the development of Indonesia. Therefore Indonesia must be able to maintain its economic, political and legal stability for the prosperity of the Indonesian people.

\section{DAFTAR PUSTAKA}

Ali, Imron. "Analisis Terhadap Kekuatan Bargaining Position pemerintah Indonesia dalam Kontrak Karya PT. Freeport Indonesia”, Jurnal Cakrawala Hukum, Volume 18, No. 2 Desember 2013.

Amelia, Dwi Astusi. "Implikasi Kebijakan Indonesia dalam Menangani Kasus Pencemaran Lingkungan oleh PT. Freeport terhadap Keamanan Manusia di Mimika Papua”, Journal of international Relation, Volume. 4, No 3, 2018. 
Amiruddin, Soare. Aderito J, Perjuangan Amungme Antara Freeport dan Militer, Insist Press Yogyakarta.s 2018.

Fatma, Dian Pratiwi, "Kontradiksi Bumi Papua: Tinjauan Kritis Program CSR PT. Freeport Indonesia di Papua", Jurnal Komunikasi, Volume 3, No.2 April 2019

Denise. Leith, Freeport and the Suharto Regime, 1965-1998, Contemporary Pacific; Spring 2002; Pg. 75.

Leith, Denise "Freeport and the Suharto Regime, 1965-1998" The Contemporary Pacific: Spring 2002, Journal Volume. 14, No.1

Lembaran Negara Republik Indonesia, Peraturan Pemerintah Republik Indonesia Nomor 1 Tahun 2017 tentang Perubahan Keempat atas Peraturan Pemerintah Nomor 23 Tahun 2010 Tentang Pelaksanaan Kegiatan Usaha Pertambangan Mineral dan Batubara.

PT. Freeport Indonesia, Berita Kita "Dari Hulu Hingga ke Hilir “, Edisi No.240 Maret 2014.

Redi, Ahmad. Kontrak Karya PT Freeport Indonesia dalam Prespektif Pancasila dan UUD NRI 1945. Journal Konstitusi, Volume 13, Nomor 3, September 2016.

Toruan, Henry D. Lbn. Pergeseran Paradigma Hukum Investasi Pertambangan. Jurnal Recths Vinding, Media Pembinaan Hukum Nasional, Volume 4, Nomor 2, Agustus 2015.

Roni Sulistyanto Luhukay, "Tanggung Jawab PT.Freeport Indonesia Terhadap Penangan Kerusakan Lingkungan Akibat Penangan Kerusakan Lingkungan Akibat Pertambangan di Kabupaten Mimika Papua" Jurnal Lex et Societatis, Vol. IV/ No. 3/Maret/2016.

Tri Ratna Rinayuhani, "Rational Choice dalam Kerjasama Pemerintah Indonesia dengan PT. Freeport Indonesia” Jurnal Kajian Politik dan Masalah Pembangunan, Vol. 13 No. 1. 2017.

Ukar W. Soelistijo, "Kronologi Kontrak karya di Indonesia dan Usaha Pertambangan PT. Freeport Indonesia (PTFI)", Prosiding SNaPP2012: Sains, Teknologi, dan Kesehatan, Vol 3, No.1, Th 2012.

Yonas Yanampa, Tri Sulistyaningsing, Asep Nurjaman, "Relasi Kerjasama Elit Kapitalis dengan Elit Lokal Tambang Emas (Studi Kasus) Timika Papua”, Seminar Nasional dan Gelar produk, SenasPro2 UMM 17 - 18 Oktober 2017.

Akbaransyah, Andhika. Kontrak Karya dan IUPK Jadi Akar Masalah Freeport, Apa Bedanya?.https://finance.detik.com/energi/d-3428820/kontrak-karya-dan-iupk-jadi-akarmasalah-freeport-apa-bedanya 10 September 2019.

BBC News Indonesia, Pemerintah Indonesia dapatkan 51\% saham dan perpanjang Kontrak Freeport. http://www.bbc.com/indonesia/indonesia-41079090 10 September 2019.

Daniel, Wahyu. Freeport dan Pemerintah Debat Soal Aturan Pajak, Apa Solusinya?https://finance.detik.com/energi/3495094/freeport-dan-pemerintah-debatsoal-aturan-pajak-apa-solusinya 10 September 2019.

Hakim, Chappy. 50 Tahun Indonesia.https://ekonomi.kompas.com/read/2017/05/30/210000526/50.tahun.freeport.di. indonesia 3 September 2019.

Lahaye, Laura The Concise Encyclopedia of Economics - Mercantilism. http://www.econlib.org/library/Enc/Mercantilism.html 3 September 2019.

Yovanda. Yanuar. R, Membuka Tabir Freeport jadi Anak Emas Era Orde Baru, https://ekbis.sindonews.com/read/1183661/34/membuka-tabir-freeport-jadi-anak-emasera-orde-baru-1488180714 3 September 2019. 